\title{
Seasonality and facilitation drive tree establishment in a semi-arid floodplain savanna
}

Megan K. Good ${ }^{A, *}$, Peter J. Clarke ${ }^{B}$, Jodi N. Price ${ }^{C}$ and Nick Reid ${ }^{A 1}$

${ }^{A}$ Ecosystem Management, School of Environmental and Rural Science, University of New England, Armidale, NSW 2351, Australia.

BBotany, School of Environmental and Rural Science, University of New England, Armidale, NSW 2351, Australia.

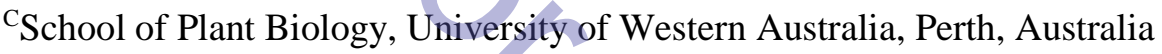
*Corresponding author. Email: m.good@latrobe.edu.au, Current address: Department of Botany, School of Life Sciences, La Trobe University, Bundoora, Vic, 3086, Phone: (03) 94718178

Running headline: Tree establishment in floodplain savanna

\footnotetext{
${ }^{1}$ Author Contributions: MKG, PJC, NR and JNP originally formulated the idea. MKG and PJC designed the experiments. MKG performed the experiments. MKG, PJC and JNP analyzed the data. MKG, JNP, PJC and NR wrote the manuscript.
} 
1 Abstract A popular hypothesis for tree and grass coexistence in savannas is that tree seedlings are

2 limited by competition from grasses. However, competition may be important in favourable climatic

3 conditions when abiotic stress is low, whereas facilitation may be more important under stressful conditions.

$4 \quad$ Seasonal and inter-annual fluctuations in abiotic conditions may alter the outcome of tree-grass interactions

5 in savanna systems and contribute to coexistence. We investigated interactions between coolibah

6 (Eucalyptus coolabah) tree seedlings and perennial $\mathrm{C}_{4}$ grasses in semi-arid savannas in eastern Australia in

7 contrasting seasonal conditions. In glasshouse and field experiments, we measured survival and growth of

8 tree seedlings with different densities of $\mathrm{C}_{4}$ grasses across seasons. In warm glasshouse conditions, where

9 water was not limiting, competition from grasses reduced tree seedling growth but did not affect tree

10 survival. In the field, all tree seedlings died in hot dry summer conditions irrespective of grass or shade

11 cover, whereas in winter, facilitation from grasses significantly increased tree seedling survival by

12 ameliorating heat stress and protecting seedlings from herbivory. We demonstrated that interactions

13 between tree seedlings and perennial grasses vary seasonally, and timing of tree germination may determine

14 the importance of facilitation or competition in structuring savanna vegetation because of fluctuations in

15 abiotic stress. Our finding that trees can grow and survive in a dense $\mathrm{C}_{4}$ grass sward contrasts with the

16 common perception that grass competition limits woody plant recruitment in savannas.

17 Keywords Australia, tree-grass coexistence, $\mathrm{C}_{4}$ grass, competition, eucalypt seedlings 
20 The coexistence of trees and grasses in savanna ecosystems has intrigued ecologists for decades and

21 produced many theories, which can be broadly grouped into resource or disturbance-based hypotheses

22 (Walter 1971; Sankaran et al. 2004; Bond 2008; February et al. 2013; Ward et al. 2013). Savannas occur

23 across a wide climatic range, often separated from densely forested vegetation by sharp boundaries,

24 suggesting they receive enough rainfall to support a much higher biomass of trees, and are limited by other

25 factors (Sankaran et al. 2004; 2005; Bond 2008). Hence, coexistence seems to be partly driven by resource

26 competition between trees and grasses, especially during tree seedling establishment when competition for

27 resources is strong (Knoop and Walker 1985; Jeltsch et al. 1996; Scholes and Archer 1997; Gignoux et al.

28 2009; Ward et al. 2013). Identifying the factors that limit tree abundance in savannas has become

29 increasingly important from a management perspective, with increases in tree density in some systems (e.g.

30 Briggs et al. 2005; Eldridge et al. 2011) and decreases in others (Fischer et al. 2009; Allen et al. 2010).

31 Demographic models of tree-grass coexistence propose that tree abundance is limited by variations

32 in seedling establishment (dependent on rainfall and competition) and limitations in transitions to adult

33 stages (fire and other disturbances; Higgins et al. 2000). Savannas may be governed by variability in

34 environmental conditions, which favours grass or tree dominance at different spatial and temporal scales,

35 and prevents either life-form from becoming dominant across the landscape (Sankaran et al. 2005; Wiegand

36 et al. 2005; 2006). Environmental variability is especially important in semi-arid savannas which are prone

37 to periods of drought interspersed with rainfall periods (Fensham and Holman 1999; Fensham et al. 2005;

38 Sankaran et al. 2005). Favourable conditions promote woody plant establishment and regeneration, while

39 droughts and fires result in woody plant decline (Fensham et al. 2009; Nano and Clarke 2010; Lawes et al.

40 2011).

41 Interactions between grasses and trees may be affected by climatic conditions especially during the

42 establishment phase when the two life-forms share the same rooting zone (Scholes and Archer 1997; Ward

43 2005; Riginos 2009; Ward and Esler 2011). This interplay between biotic and abiotic factors may determine 
44 ecosystem structure, especially in bistable systems such as savannas (Tylianakis et al. 2008; Volder et al. 45 2013). For example, February et al. (2013) found increased rainfall gave grasses a competitive advantage 46 over tree seedlings. Indeed, many studies have reported grasses can inhibit woody plant recruitment through 47 competition (Davis et al. 1998; Ball et al. 2002; Bloor et al. 2008; Clarke and Knox 2009; Messier et al. 48 2009). However, facilitation can also be vital for seedling recruitment in severe environments where 49 established plants provide a beneficial microclimate beneath their canopies (Belsky et al. 1989; Callaway et 50 al. 2002; Brooker et al. 2008; Anthelme and Michalet 2009; Bustamante-Sánchez et al. 2011). Newly 51 germinated and young seedlings are susceptible to non-resource based stresses, such as excessive solar 52 radiation and extreme temperatures (Osmond et al. 1987; Ferrar et al. 1989; Niinemets 2010), and protection 53 from these stresses can increase seedling survival. These effects are particularly important in semi-arid and 54 arid environments where light and heat stress in exposed areas are responsible for high seedling mortality 55 (Björkman and Powles 1984; Osmond et al. 1987; Callaway 1995; Gómez-Aparicio et al. 2008). In addition, 56 a number of studies have found facilitative effects of grasses on seedlings by reducing visibility to 57 herbivores (Western and Maitumo 2004; Riginos and Young 2007; Porensky and Veblen 2012). However, neighbouring plants may compete for soil resources below-ground while simultaneously ameliorating nonresource-based stress. Indeed, below-ground competition can be intense in semi-arid and arid environments where soil moisture availability is limited (Pugnaire and Luque 2001; Nano and Clarke 2010). The overall aim of this study was to investigate the ability of grasses to suppress or facilitate tree seedling establishment under seasonally variable conditions. Semi-arid floodplains dominated by coolibah

63 (Eucalyptus coolabah subsp. coolabah) trees in inland eastern Australia are a useful model system to 64 investigate the effects of seasonal variability on tree-grass interactions because they undergo a wide range 65 of environmental conditions, from droughts to high rainfall periods and flooding. Tree establishment in 66 these systems can occur en masse following flooding and high rainfall periods, which can occur at any time 67 of the year. However, these recruitment events are rare and this has resulted in patches of even-aged stands 68 of trees (with very high stem densities, 2300 ha; Good et al. 2011). Cohorts are generally separated by 
69 several decades (the last successful cohort regenerated 40 years ago) due to the low success rate of 70 regeneration (Good et al. 2012). Tree seedling germination followed by a period of high abiotic stress may 71 reduce tree establishment (Castro et al. 2005), or increase the importance of positive plant-plant interactions

72 (Gómez-Aparicio et al. 2008; Anthelme and Michalet 2009). That is, favourable climatic conditions (in $73 \mathrm{cool} /$ wet seasons or during years of high rainfall) may dramatically improve tree establishment rates or 74 alternatively result in an increase in the importance of competitive interactions among plants (February et 75 al. 2013).

We evaluated the importance of competitive and facilitative interactions between grasses and tree 77 seedlings in different seasons by conducting field and glasshouse experiments. We asked: (1) do grasses 78 facilitate or compete with tree seedlings? (2) Is tree seedling growth and survival affected by seasonal 79 conditions, and does seasonality alter tree-grass interactions? (3) Is above or below-ground competition, for 80 light or soil resources, respectively, more important for tree seedling growth?

\section{Materials and methods}

\section{Study system}

83 The floodplains of mid latitudinal inland eastern Australia consist of a continuous $\mathrm{C}_{4}$ grassy ground layer 84 with discontinuous eucalypt cover of varying density, from treeless grasslands to dense woodlands. The 85 dominant floodplain tree on the alluvial cracking clay soils in this region is Eucalyptus coolabah subsp. 86 coolabah (hereafter coolibah). Coolibah seeds germinate at a range of temperatures with an optimum 87 temperature of around $30-35{ }^{\circ} \mathrm{C}$ (Doran and Boland 1984). The soil surface can reach this temperature on 88 sunny days throughout the year, even in winter months. For this reason, it is likely that seedling emergence 89 is most limited by moisture availability and is generally restricted to high rainfall periods and/or periods 90 immediately following flood recession (which can occur at any time of the year but are more common in 91 summer). We chose three sites of 20-50 ha of grassland (with scattered remnant trees, $\sim 2-5$ ha $^{-1}$ ), within 5 $92 \mathrm{~km}$ of one another $\left(149^{\circ} 13^{\prime} \mathrm{E}, 30^{\circ} 5^{\prime} \mathrm{S}\right)$ to conduct the field experiments. Mean annual rainfall of the study 93 area is $597 \mathrm{~mm}$ (Wee Waa weather station; Australian Bureau of Meteorology 2012) with a slight peak in 
94 summer (January). Summers are hot (mean minimum of the hottest month is $30^{\circ} \mathrm{C}$ and the mean monthly 95 maximum is $37^{\circ} \mathrm{C}$ in January) and winters are mild (mean minimum of the coldest month is $1^{\circ} \mathrm{C}$ and the mean monthly maximum is $21^{\circ} \mathrm{C}$ in July). All sites were grazed by livestock in the past but cattle had been excluded for 4 years and the grasslands had recovered and were dominated by native perennial grasses (primarily Panicum decompositum and Paspalidium jubiflorum).

\section{Field experiments}

We implemented three treatments, each replicated four times per site: (1) maximum grass cover (GRASS) with no grass removal; (2) zero grass cover (BARE) with all vegetation clipped and poisoned with glyphosate 2 weeks prior to transplanting of coolabah seedlings and maintained by hand weeding throughout the study, and (3) zero grass cover plus shade (SHADE) with all vegetation treated as in (2), but with $70 \%$ shade cloth covering the plot at a height of $50 \mathrm{~cm}$. At each site, a $10 \times 10-\mathrm{m}$ experimental grid was established at least $50 \mathrm{~m}$ from trees in grassland of relatively homogeneous composition and subdivided into sixteen $2.5 \times 2.5$-m plots. Treatments were randomly assigned to plots. Within each plot, a central subplot of $0.5 \times 0.5 \mathrm{~m}$ was marked and coolibah seedlings were transplanted into these subplots on two occasions (summer and winter). Each subplot was surrounded by a buffer of $1 \mathrm{~m}$ to minimise disturbance and to ensure the treatments extended $>1 \mathrm{~m}$ in each direction from transplanted seedlings. Coolibah seed was obtained from commercial seed suppliers who sourced seeds from within $50 \mathrm{~km}$ of the study sites. The same seed lot was used for all experiments. Coolibah seeds were germinated and seedlings grown in soils collected from the study region and used in all three experiments. Prior to transplanting, seedlings were grown for 1-2 months to a height of $1-2 \mathrm{~cm}$.

For the summer 2010 seedling transplant experiment, five coolibah seedlings were planted in each subplot, 25-30 cm apart, and watered immediately with $2 \mathrm{~L}$ of rainwater. Plots were then watered with $1 \mathrm{~L}$ of rainwater every evening (after 1700 hours) for 6 days. For the winter 2010 seedling transplant, seven seedlings were planted in each subplot, 25-30 cm apart, and watered immediately with $1 \mathrm{~L}$ of rainwater. Rainfall in the weeks prior to planting and mild winter temperatures meant that the soil was moist and did 
not require much watering. We lightly watered all plots $(<1 \mathrm{~L})$ every second day for the first week and seedlings received natural rainfall for the remainder of the study. Following transplanting of tree seedlings

121 in summer (March 2010), we recorded seedling survival on days 2, 4, 7 and 14 (after transplant). In the 122 winter experiment (August 2010), we monitored seedling survival and height on days 10, 14, and 27 (after 123 transplant), and then approximately monthly until the end of the experiment in April 2011 (apart from 124 December 2010 when sites were flooded). Seedlings were considered 'dead' if they were missing, had no 125 leaves, or if their leaves were brown and desiccated. Death was recorded as abiotic stress if the leaves were 126 brown and desiccated, and in the winter experiment we recorded evidence of herbivory.

Rainfall and temperature data for the closest stations to the study site were downloaded from the 128 Australian Bureau of Meteorology Climate Data Online service (Australian Bureau of Meteorology, 2012).

129 We recorded soil moisture at all sites each time we monitored seedlings, using a soil moisture probe 130 (ThetaProbe; Delta-T Devices 1998), which indirectly measures volumetric moisture content by measuring electrical conductivity. We took five readings of soil moisture haphazardly throughout sites on each visit.

132 Soil moisture in the summer field experiment averaged approximately 30\%, but was still well above wilting 133 point (Stace et al. 1968; McKenzie et al. 2004). In the glasshouse and in the winter field experiment soil 134 moisture was $~ 35 \%$ due to regular watering (in the glasshouse) and mild conditions (in the field). 135 Temperature loggers (iButtons ${ }^{\circledR}$ ) were used to record soil surface temperatures and were placed on the soil 136 surface, face down, attached to a small plastic holder and pinned to the ground. They recorded temperatures 137 at 2-h intervals throughout each experiment. In March, temperature loggers were placed in eight subplots 138 (two GRASS, three BARE and three SHADE) and, in August, temperature loggers were placed in 20 plots 139 (six GRASS, seven BARE and seven SHADE). We used a light meter to measure photosynthetically active 140 radiation (PAR) at each seedling between 1130 and $1200 \mathrm{~h}$ on a cloudless day, midway through and at the 141 end of the winter experiment, and midway through the glasshouse experiment (see below). Light availability 142 in BARE plots in the field and in CONTROL plots in the glasshouse were considered to be the maximum 143 light availability in each experiment since these treatments were in full sunlight. 
144 Above and below-ground resource manipulations

145 After 81 days ( 3 months) in the winter experiment, we manipulated light availability in GRASS plots in 146 order to investigate the effects of above and below-ground competition on seedling growth. We used wire 147 to hold back the foliage of grasses in some of the GRASS plots so that light availability for seedlings 148 increased (high light) but grass roots were still present. In 'low' and 'high' light treatments, light availability 149 was $<500$ and $>700 \mu \mathrm{mol} \mathrm{m} \mathrm{m}^{-2} \mathrm{~s}^{-1}$, respectively. In 'low' light treatments mean ( $\pm \mathrm{SE}$ ) light availability was $150351( \pm 31) \mu \mathrm{mol} \mathrm{m} \mathrm{m}^{-2} \mathrm{~s}^{-1}$ and in 'high’ light treatments it was $1253( \pm 70) \mu \mathrm{mol} \mathrm{m} \mathrm{m}^{-2} \mathrm{~s}^{-1}$. BARE plots were 151 high-light treatments without root competition (first 3 months, $n=15$ seedlings; second 3 months, $n=3$ 152 seedlings) and SHADE plots were low-light treatment without root competition (first 3 months, $n=37$ 153 seedlings; second 3 months, $n=16$ seedlings). GRASS plots with light availability $>700 \mu \mathrm{mol} \mathrm{m}^{-2} \mathrm{~s}^{-1}$ were 154 high-light treatments with root competition (first 3 months, $n=20$ seedlings; second 3 months, $n=15$ 155 seedlings). GRASS plots with light availability $<500 \mu \mathrm{mol} \mathrm{m}{ }^{-2} \mathrm{~s}^{-1}$ were low-light treatments with root 156 competition (first 3 months, $n=42$ seedlings; second 3 months, $n=3$ seedlings).

157 Glasshouse experiment

158 Grass tussocks (Paspalidium jubiflorum) were collected from ten locations near the field sites 2 months 159 prior to the experiment using the Whalley method (Whalley and Brown 1973). Round plastic pots (20 cm diameter $\times 20 \mathrm{~cm}$ deep) were lined with absorbent paper, filled with $2 \mathrm{~cm}$ of sand, and filled to $2 \mathrm{~cm}$ from the top with field soil. Grass tussocks were separated into smaller parts so that each basal diameter was approximately $2 \mathrm{~cm}$ and planted into pots, $5 \mathrm{~cm}$ apart, in two densities (2 or 4 tussocks per pot). Grasses were grown and watered regularly for 1 month prior to sowing coolibah seeds to allow them to establish.

164 Pots were placed in a glasshouse maintained at $30^{\circ} \mathrm{C}$ and $20^{\circ} \mathrm{C}$, day and night respectively, to mimic optimal 165 grass growing conditions (summer). A small amount of coolibah seed was added to the centre of the pots, 166 and the resulting seedlings later thinned to one per pot. Soils were kept saturated until seeds germinated 167 thereafter pots were watered every 2 days with $500 \mathrm{~mL}$ of water until the end of the experiment. 

maximum of $30 \mathrm{~cm}$ (LONG) at which point they were clipped to reduce shading of neighbouring pots. The treatments were: (1) CONTROL: tree seedlings grown without competition ( $n=26$ seedlings); (2) $2 \times$

172 GRASS: tree seedlings grown with two grass tussocks with two clipping treatments (LONG: $n=12$ 173 seedlings, SHORT: $n=12$ seedlings); and (3) $4 \times$ GRASS: tree seedlings grown with four grass tussocks 174 with two clipping treatments (LONG: $n=12$ seedlings or SHORT: $n=12$ seedlings).

Seedling height was measured at week 3, 4 and 5, and after 2 months of growth all grasses and seedlings were harvested, dried and weighed. Seedling biomass was used to calculate Relative Competition 177 Intensity ( $\left.\mathrm{RCI}_{\text {biomass}}\right)$ (Wilson and Keddy 1986) using the following equation:

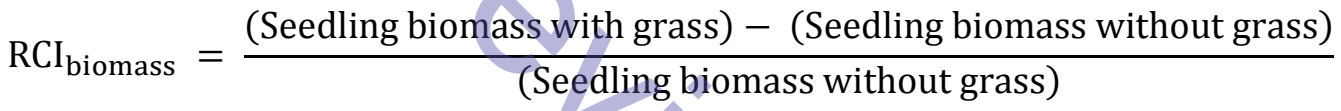

Data analyses

To test the significance of treatment effects on soil surface temperatures, tree seedling growth and survival, seedling death from herbivory and final seedling measurements in the two field experiments, we used a twofactor ANOVA with grass treatment (three levels: BARE, GRASS and SHADE) and site $(n=3)$ as factors. When site $\times$ treatment interactions were not significant $(P>0.05)$, sites were pooled. Bonferroni post hoc comparisons were carried out when significant treatment effects were found. Data were square root or logtransformed where necessary to satisfy ANOVA assumptions of normality and homogeneity of variance. To compare above and below-ground competition in the winter field experiment, we compared tree seedling growth with and without root competition under high and low light availability in the first 3 months separately from the second 3 months, since the latter period coincided with the summer growing season.

190 For each time period, we used a two-factor ANOVA, with light availability (high vs low) and root 191 competition (with and without) as factors. Bonferroni post hoc comparisons were undertaken when 
193 Intensity ( $\mathrm{RCI}_{\text {biomass }}$ ) in the glasshouse experiment, we used one-way ANOVA. To investigate the 194 importance of above-ground competition in the glasshouse experiment, we compared $\mathrm{RCI}_{\text {biomass }}$ of the 195 clipped and unclipped grass treatments, using a two-factor ANOVA with clipping and grass density as 196 factors.

\section{Results}

198 Abiotic conditions in the field and glasshouse

199 Abiotic conditions in the field differed between seasons; daily maximum temperatures were higher in 200 summer $\left(>10^{\circ} \mathrm{C}\right.$ higher than winter temperatures for most of the first 2 weeks) whereas rainfall was more 201 frequent at the beginning of the winter experiment (Appendix 1). Maximum temperatures in the summer 202 experiment ranged from $24^{\circ} \mathrm{C}$ to $34^{\circ} \mathrm{C}$ in the 2 weeks following tree seedling transplant. Daily maxima for 203 the first 2 weeks of the winter experiment ranged from $13^{\circ} \mathrm{C}$ to $23^{\circ} \mathrm{C}$ but were $<20^{\circ} \mathrm{C}$ most of the time 204 (Appendix 1). Light availability was much lower ( $\sim 40 \%$ reduction) and soil moisture was higher in the 205 glasshouse than in the field. As the winter field experiment progressed, daily temperature maxima increased 206 and rainfall was regular, with high daily rainfall on many days in early summer (Appendix 2). The high 207 rainfall resulted in floods and all three experimental sites were inundated for varying amounts of time. Two 208 of the sites were only inundated for 2 weeks and sustained little damage; aerial parts of the grasses were 209 killed but they soon re-sprouted and grew vigorously as soon as the sites dried. The third site was inundated 210 for $>2$ months and had to be abandoned. When the site eventually dried out, all of the seedlings and 211 herbaceous plants had died.

212 In both summer and winter, daily maximum soil surface temperatures in BARE plots were 213 consistently higher and more variable than SHADE and GRASS plots, which did not differ from each other 214 (Fig. 1). In the summer experiment, soil surface temperatures in BARE plots exceeded $60^{\circ} \mathrm{C}$ on 4 days when 215 daily maximum temperatures were around $33^{\circ} \mathrm{C}$, and were consistently hotter than in winter. 
217 Tree seedling survival in the glasshouse was 100\% over the 2-month duration of the experiment, whereas 218 seedling survival in the field was low. Transplanted tree seedlings did not survive the summer conditions 219 for more than 2 weeks, even with protection from full sun and extreme heat (90\% of seedlings were dead 220 within 2 weeks and 100\% were dead after 3 weeks; Fig. 2). Seedling survival in winter was higher, with 221 only 7\% of tree seedlings dead after 2 weeks (Fig. 3).

Tree seedling survival was consistently higher in GRASS and SHADE than BARE plots throughout 223 the winter experiment and there were no significant site $\times$ treatment interactions (Fig. 3). Differences in the 224 survival of seedlings between SHADE and GRASS treatments were initially significant, with lower survival 225 of SHADE seedlings in the first 3 months; thereafter they became similar. Herbivory of tree seedlings was 226 not recorded in the summer experiment because of rapid mortality that was presumably due to stress (as 227 most seedlings appeared desiccated). In the winter transplant, cause of seedling death varied significantly 228 between treatments but not between sites, the site $\times$ treatment interaction being not significant. The mean 229 percentage of seedling death from herbivory was significantly higher in BARE plots (37 \pm 6\%) and SHADE 230 (30 $\pm 5 \%$ ) than GRASS (5 $\pm 3 \%$ ) plots throughout the study. This was mostly driven by the high rate of 231 seedling herbivory in the first month (August) of the experiment.

232 Tree seedling growth and competition intensity

233 Seedling growth was not measured during the summer experiment due to rapid seedling mortality. In the

234 first 3 months of the winter experiment, seedling growth was slow and there was no significant difference 235 in seedling height among treatments or among sites (Fig. 4). Between December and January, growth of 236 tree seedlings increased and treatment differences became significant (with no significant site $\times$ treatment 237 interaction). Tree seedlings in GRASS plots were significantly smaller than seedlings in BARE and SHADE 238 plots, which did not differ throughout the study. At the end of the study, SHADE seedlings were 239 significantly larger than GRASS tree seedlings in both height and biomass (Table 1). Only one seedling 240 remained in BARE plots at the end of the study, it being larger than any seedlings in GRASS plots (Table 241 1). These results were reflected in the glasshouse experiment with mean tree seedling height significantly 
242 greater in BARE pots than in pots with two grass tussocks, and both were greater than seedling height in

243 pots with four grass tussocks (Fig. 5).

244 Below-ground vs above-ground competition

245 There were no significant above or below-ground competition effects in the first 3 months of the winter 246 field experiment (Table 2). In the second 3 months of the experiment, root competition effects were 247 significant but there were no significant light or light $\times$ root effects. When light levels were pooled, the 248 presence of roots significantly reduced seedling growth (Table 2). Tree seedlings grown without root 249 competition grew more than twice as much as seedlings grown with root competition (Table 2).

In the glasshouse experiment, reducing above-ground biomass (clipping) did not significantly reduce 251 competition intensity (Fig. 5). Clipped (SHORT) grasses were not significantly different, in terms of 252 competition intensity, to unclipped (LONG) within density treatments (Fig. 5). There was, however, a 253 significant difference between the $4 \times$ GRASS LONG treatment and the $2 \times$ GRASS SHORT treatment. 254 Light availability in these treatments differed significantly (mean maximum light availability of $595 \pm 64$ 255 and $855 \pm 44 \mu \mathrm{mol} \mathrm{m} \mathrm{m}^{-2} \mathrm{~s}^{-1}$, respectively) but the reduction in light availability did not significantly reduce 256 seedling growth relative to the clipped treatments (Fig. 5).

\section{Discussion}

258 We investigated the effect of season on tree-grass interactions in a semi-arid savanna by comparing the 259 effects of perennial grasses on tree seedling growth and survival in the field over summer and winter, and 260 in the glasshouse under optimal growing conditions. In summer, no tree seedlings survived regardless of 261 grass cover due to very high temperatures and dry conditions immediately after planting, demonstrating the 262 importance of seasonal and abiotic conditions. In cooler, humid winter conditions, grasses and shade 263 significantly increased tree seedling survival compared to seedlings growing in the open (only one survivor), 264 demonstrating that grasses facilitated survival under less stressful conditions. All seedlings survived 265 irrespective of grass cover under optimal glasshouse conditions where temperatures were warm, moisture 266 was not limiting, but solar radiation was reduced. Root competition significantly decreased seedling growth, 
267 with seedlings about twice the size in shade plots compared to grass. In this savanna, conditions benign 268 enough to allow seedling survival without protection from stressors do not occur, even in the coolest, wettest 269 months, and the amelioration of these stressors from neighbouring plants is vital for tree seedling survival 270 - supporting a demographic model of coexistence (Higgins et al. 2000; Sankaran et al. 2005).

271 Grasses facilitate survival of newly germinated tree seedlings

272 In the winter experiment, grass and shade cover significantly increased the survival of tree seedlings relative 273 to bare plots, whereas in the summer experiment all seedlings died irrespective of grass cover or shade.

274 Seedling mortality in bare plots was likely mostly due to heat stress; soil surface temperatures exceeded $27560^{\circ} \mathrm{C}$ in summer and reached $40^{\circ} \mathrm{C}$ in winter in bare plots, whereas temperatures beneath grasses and shade 276 cloth were significantly lower and less variable in both seasons. Plant tissue damage is thought to occur at 277 temperatures around $50-60^{\circ} \mathrm{C}$ in many species so it is not surprising that seedlings in bare soil did not 278 survive long in summer. Temperature extremes denature proteins and damage cell structure, which can be 279 tolerated in the short term but long-term exposure is fatal (Wang et al. 2003). Hence, shade from adjacent 280 plants can be critical (Flores and Jurado 2003). Newly germinated seedlings are particularly susceptible to 281 damage caused by temperature and solar radiation since they grow close to the soil surface where these 282 factors can be highly variable (Nobel 1984; Osmond et al. 1987; Helgerson 1989). Grass cover provides a 283 favourable microclimate in arid environments by reducing atmospheric aridity at ground level (Anthelme 284 and Michalet 2009). Therefore, the primary mechanism by which grass and shade increased tree seedling 285 survival in our study was through amelioration of heat and light stress and potentially a reduction in soil 286 water loss (but this was not directly measured). 289 bare plots, and although the identity of the herbivores was unclear, they were most likely insects or small 290 vertebrates. Insect herbivory is common in eucalypts and has been responsible for the dieback of mature 291 trees throughout Australia (Landsberg and Wylie 1983; Stone and Bacon 1995). The timing of herbivory in 
292 the first month of the winter transplant experiment suggests that either the young seedlings were more 293 susceptible to herbivory or that herbivores were more common at this time of the year. Herbivory has been 294 implicated in seedling mortality in other savanna systems (e.g. Western and Maitumo 2004; Riginos and 295 Young 2007; Porensky and Veblen 2012). Similar to the current study, Riginos and Young (2007) found 296 that grass cover facilitated Acacia saplings by protecting them from herbivory in an African savanna, 297 although in this case the net effect of grasses was negative due to competition. Our results suggest that grass 298 facilitation may be critical for tree establishment in semi-arid savannas, despite negative effects of grass on 299 tree seedling growth.

300 Plant-plant interactions vary with abiotic stress

301 We found that grasses reduce the growth of tree seedlings. However, the positive effects of grasses - the 302 amelioration of light and heat stress, and protection from herbivory - outweigh these negative effects by 303 enhancing seedling survival. Other studies have reported competition becoming less important as stress 304 increases (Holmgren et al. 1997; Davis et al. 1999; Pugnaire and Luque 2001). Pugnaire and Luque (2001) 305 found that the change in plant-plant interactions along stress gradients is driven more by the increase in the 306 positive effect of the nurse plant than by the decrease in the intensity of competition. Contrary to these 307 studies, and the stress-gradient hypothesis, we found that facilitation was more important with less abiotic 308 stress, as conditions in summer were too harsh for survival even with grass cover. Measuring net effects of 309 plant-plant interactions (in terms of seedling survival) is vital because the intensity of competitive 310 interactions alone (i.e. the reduction in seedling growth) may not be as relevant in determining community 311 membership. In addition, seasonality interacts with other abiotic and biotic factors in complex ways to shift 312 the relative importance of competition and facilitation in savannas (Veblen 2008).

313 Below-ground competition between grass and tree seedlings

314 As expected, below-ground competition for soil resources was the main form of competition between 315 grasses and tree seedlings in this study. Other studies have reported reduced woody seedling success when 316 grown in herbaceous vegetation in semi-arid and arid environments; this is generally attributed to below- 
317 ground competition for soil moisture (Fowler 1986; Harrington 1991; Scholes and Archer 1997; Florentine

318 and Fox 2003; Bloor et al. 2008; van der Waal et al. 2009). It is not surprising, given frequent light saturation

319 in this environment, that below-ground resources are likely to be most limiting. Soil resources were not

320 manipulated in this study so whether nutrients or water were limiting is unknown, but it is likely that water

321 is generally most limiting in the fertile clay soils of our semi-arid study region.

322 Implications for tree-grass coexistence in savannas

323 Our results provide support for demographic models of tree-grass coexistence, in which tree abundance is

324 limited by the rarity of conditions suitable for tree recruitment (Higgins et al. 2000). We found that tree

325 seedling survival is dependent on favourable seasonal conditions as well as facilitation from grasses. Similar

326 results have been reported for Eucalyptus victrix in semi-arid floodplains in Western Australia, where no

327 seedlings survived following natural, flood-induced germination, irrespective of herbaceous cover (Fox et

328 al. 2004). Other studies have found that periods of high rainfall and seed availability overwhelm the effect

329 of grasses in limiting tree regeneration in savannas (Ward 2005; Kraaij and Ward 2006). These findings are

330 contrary to the common belief that grasses limit tree seedling survival (and hence abundance) in savannas.

331 However, grasses may indirectly limit tree abundance in fire-prone savannas: seedlings growing among a

332 dense grass sward are more likely to be killed by fire (Bond 2008). Fire is rare in our study system, but other

333 disturbances such as drought and flooding may kill tree seedlings and further limit tree abundance.

334 The climatic conditions required for successful tree recruitment may be rare enough, in space and 335 time, to limit tree cover in this landscape (Wiegand et al. 2006; Moustakas et al. 2010). Winter flooding or 336 unseasonably mild summer conditions as well as adequate grass cover appear to be prerequisites for coolibah 337 recruitment. Our findings support a demographic bottleneck model of savanna stability, in which the rarity 338 of conditions suitable for successful tree recruitment restricts tree cover in the landscape (Higgins et al. 339 2000; Sankaran et al. 2004). 
341 Centre in collaboration with the Namoi and Central West Catchment Management Authorities. We thank landholders

for allowing access to sites and sharing local knowledge, Nick Schultz, Rhiannon Smith, Morag Stewart and Peter laws of Australia in which the experiments were performed.

\section{References}

Australian Bureau of Meteorology (2012) Climate data online, http://www.bom.gov.au/climate/data/ overview of drought and heat-induced tree mortality reveals emerging climate change risks for forests. For Ecol Manage 259, 660-84

Anthelme F. \& Michalet R. (2009) Grass-to-tree facilitation in an arid grazed environment (Aïr Mountains, Sahara). Basic Appl Ecol 10, 437-46

Ball M., Egerton J., Lutze J., Gutschick V. \& Cunningham R. (2002) Mechanisms of competition: thermal inhibition of tree seedling growth by grass. Oecologia 133, 120-30

Belsky A. J., Amundson R. G., Duxbury J. M., Riha S. J., Ali A. R. \& Mwonga S. M. (1989) The effects of trees on their physical, chemical, and biological environments in a semi-arid savanna in Kenya. $\mathrm{J}$ Appl Ecol 26, 1005-24

Björkman O. \& Powles S. B. (1984) Inhibition of photosynthetic reactions under water stress: interaction with light level. Planta 161, 490-504

Bloor J. M. G., Leadly P. W. \& Barthes L. (2008) Responses of Fraxinus excelsior seedlings to grassinduced above- and below-ground competition. Plant Ecol 194, 293-304

Bond W. J. (2008) What limits trees in $\mathrm{C}_{4}$ grasslands and savannas? Annu Rev Ecol Evol Syst 39, 641-59

Briggs J. M., Knapp A. K., Blair J. M., Heisler J. L., Hoch G. A., Lett M. S. \& McCarron J. K. (2005) An ecosystem in transition: causes and consequences of the conversion of mesic grassland to shrubland. BioScience 55, 243-54

Brooker R. W., Maestre F. T., Callaway R. M., Lortie C. L., Cavieres L. A., Kunstler G., Liancourt P., Tielbörger K., Travis J. M. J., Anthelme F., Armas C., Coll L., Corcket E., Delzon S., Forey E., Kikvidze Z., Olofsson J., Pugnaire F., Quiroz C. L., Saccone P., Schiffers K., Seifan M., Touzard 
B. \& Michalet R. (2008) Facilitation in plant communities: the past, the present, and the future. J Ecol 96, 18-34

Bustamante-Sánchez M. A., Armesto J. J. \& Halpern C. B. (2011) Biotic and abiotic controls on tree colonization in three early successional communities of Chiloé Island, Chile. J Ecol 99, 288-99.

Callaway R. (1995) Positive interactions among plants. Bot Rev 61, 306-49

Callaway R. M., Brooker R. W., Choler P., Kikvidze Z., Lortie C. J., Michalet R., Paolini L., Pugnaire F., Newingham B., Aschehoug E. T., Armas C., Kikodze D. \& Cook B. J. (2002) Positive interactions among alpine plants increase with stress. Nature 417, 844 - 8

Castro J., Zamora R., Hódar J. A. \& Gómez J. M. (2005) Alleviation of summer drought boosts establishment success of Pinus sylvestris in a mediterranean mountain: an experimental approach. Plant Ecol 181,191-202

Clarke P. J. \& Knox K. J. E. (2009) Trade-offs in resource allocation that favour resprouting affect the competitive ability of woody seedlings in grassy communities. J Ecol 97, 1374-82

Davis M. A., Wrage K. J. \& Reich P. B. (1998) Competition between tree seedlings and herbaceous vegetation: support for a theory of resource supply and demand. J Ecol 86, 652-61

Davis M. A., Wrage K. J., Reich P. B., Tjoelker M. G., Schaeffer T. \& Muermann C. (1999) Survival, growth, and photosynthesis of tree seedlings competing with herbaceous vegetation along a water-light-nitrogen gradient. Plant Ecol 145, 341-50

Devices D.-T. (1998) ThetaProbe soil moisture sensor Type ML2, user manual-ML2-UM-1. Delta-T Devices LTD, Cambridge

Doran J. C. \& Boland D. J. (1984) Effects of temperature on germination of Eucalyptus microtheca. Aust For Res 14, 49-55

Eldridge D. J., Bowker M. A., Maestre F. T., Roger E., Reynolds J. F. \& Whitford W. G. (2011) Impacts of shrub encroachment on ecosystem structure and functioning: towards a global synthesis. Ecol Lett 14, 709-22

February E. C., Higgins S. I., Bond W. J. \& Swemmer L. (2013) Influence of competition and rainfall manipulation on the growth responses of savanna trees and grasses. Ecology 94, 1155-64

Fensham R. J., Fairfax R. J. \& Archer S. R. (2005) Rainfall, land use and woody vegetation cover change in semi-arid Australian savanna. J Ecol 93, 596-606

Fensham R. J., Fairfax R. J. \& Ward D. P. (2009) Drought-induced tree death in savanna. Glob Chang Biol 15, 380-7

Fensham R. J. \& Holman J. E. (1999) Temporal and spatial patterns in drought-related tree dieback in Australian savanna. J Appl Ecol 36, 1035-50 
Ferrar P., Slatyer R. \& Vranjic J. (1989) Photosynthetic temperature acclimation in Eucalyptus species from diverse habitats, and a comparison with Nerium oleander. Funct Plant Biol 16, 199-217

Fischer J., Stott J., Zerger A., Warren G., Sherren K. \& Forrester R. I. (2009) Reversing a tree regeneration crisis in an endangered ecoregion. Proc Natl Acad Sci U S A 106, 10386-91

Florentine S. K. \& Fox J. E. D. (2003) Competition between Eucalyptus victrix seedlings and grass species. Ecol. Res. 18, 25 - 39

Flores J. \& Jurado E. (2003) Are nurse-protégé interactions more common among plants from arid environments? J Veg Sci 14, 911-6

Fowler N. (1986) The role of competition in plant communities in arid and semiarid regions. Annu Rev Ecol Syst 17, 89-110

Fox J. E. D., Florentine S. K. \& Westbrooke M. E. (2004) Observations on survival and early growth of natural regeneration in floodplain coolibah Eucalyptus victrix (Myrtaceae) in the Pilbara, Western Australia. Rangel J 26, 150-60

Gignoux J., Lahoreau G., Julliard R. \& Barot S. (2009) Establishment and early persistence of tree seedlings in an annually burned savanna. J Ecol 97, 484-95

Gómez-Aparicio L., Zamora R., Castro J. \& Hódar J. A. (2008) Facilitation of tree saplings by nurse plants: microhabitat amelioration or protection against herbivores? J Veg Sci 19, 161-72

Good M. K., Price J. N., Clarke P. J. \& Reid N. (2011) Densely regenerating coolibah (Eucalyptus coolabah) woodlands are more species rich than surrounding derived grasslands in floodplains of eastern Australia. Aust J Bot 64, 468-79

Good M. K., Price J. N., Clarke P. J. \& Reid N. (2012) Dense regeneration of floodplain Eucalyptus coolabah: invasive scrub or passive restoration of an endangered woodland community? Rangel $\mathrm{J}$ 34, 219-30

Harrington G. N. (1991) Effects of soil moisture on shrub seedling survival in a semi-arid grassland. Ecology 72, 1138-49

Helgerson O. T. (1989) Heat damage in tree seedlings and its prevention. New Forest 3, 333-58

Holmgren M., Scheffer M. \& Huston M. A. (1997) The interplay of facilitation and competition in plant communities. Ecology 78, 1966-75

Higgins S. I., Bond W. J. \& Trollope W. S. W. (2000) Fire, resprouting and variability: a recipe for grasstree coexistence in savanna. $\mathrm{J}$ Ecol 88, 213-29

Jeltsch F., Milton S. J., Dean W. R. \& Van Rooyen N. (1996) Tree spacing and coexistence in semiarid savannas. J Ecol 84, 583-95

Knoop W. T. \& Walker B. H. (1985) Interactions of woody and herbacous vegetation in a southern African savanna. J Ecol 73, 235-53 
Kraaij T. \& Ward D. (2006) Effects of rain, nitrogen, fire and grazing on tree recruitment and early survival in bush-encroached savanna, South Africa. Plant Ecol 186, 235-46

Landsberg J. \& Wylie F. R. (1983) Water stress, leaf nutrients and defoliation: a model of dieback of rural eucalypts. Aust J Ecol 8, 27-41

Lawes M. J., Murphy B. P., Midgley J. J. \& Russell-Smith J. (2011) Are the eucalypt and non-eucalypt components of Australian tropical savannas independent? Oecologia 166, 229-39

McKenzie N., Jacquier D., Isbell R. \& Brown K. (2004) Australian soils and landscapes: an illustrated compendium. CSIRO publishing, Collingwood

Messier C., Coll L., Poitras-Lariviere A., Belanger N. \& Brisson J. (2009) Resource and non-resource root competition effects of grasses on early versus late-successional trees. J Ecol 97, 548-54

Moustakas A., Wiegand K., Meyer K. M., Ward D. \& Sankaran M. (2010) Learning new tricks from old trees: revisiting the savanna question. Front Biogeogr 2, 31-4

Nano C. \& Clarke P. (2010) Woody-grass ratios in a grassy arid system are limited by multi-causal interactions of abiotic constraint, competition and fire. Oecologia 162, 719-32

Niinemets Ü. (2010) Responses of forest trees to single and multiple environmental stresses from seedlings to mature plants: Past stress history, stress interactions, tolerance and acclimation. Forest Ecol Manag 260, 1623-39

Nobel P. S. (1984) Extreme temperatures and thermal tolerances for seedlings of desert succulents. Oecologia 62, 310-7

Osmond C. B., Austin M. P., Berry J. A., Billings W. D., Boyer J. S., Dacey J. W. H., Nobel P. S., Smith S. D. \& Winner W. E. (1987) Stress physiology and the distribution of plants. BioScience 37, 3848

Porensky L. \& Veblen K. (2012) Grasses and browsers reinforce landscape heterogeneity by excluding trees from ecosystem hotspots. Oecologia 168, 749-59

Pugnaire F. I. \& Luque M. T. (2001) Changes in plant interactions along a gradient of environmental stress. Oikos 93, 42-9

Riginos C. (2009) Grass competition suppresses savanna tree growth across multiple demographic stages. Ecology 90, 335-40

Riginos C. \& Young T. (2007) Positive and negative effects of grass, cattle, and wild herbivores on Acacia saplings in an East African savanna. Oecologia 153, 985-95

Sankaran M., Hanan N. P., Scholes R. J., Ratnam J., Augustine D. J., Cade B. S., Gignoux J., Higgins S. I., Le Roux X., Ludwig F., Ardo J., Banyikwa F., Bronn A., Bucini G., Caylor K. K., Coughenour M. B., Diouf A., Ekaya W., Feral C. J., February E. C., Frost P. G. H., Hiernaux P., Hrabar H., 
Metzger K. L., Prins H. H. T., Ringrose S., Sea W., Tews J., Worden J. \& Zambatis N. (2005) Determinants of woody cover in African savannas. Nature 438, 846-9

Sankaran M., Ratnam J. \& Hanan N. P. (2004) Tree-grass coexistence in savannas revisited - insights from an examination of assumptions and mechanisms invoked in existing models. Ecol Lett 7, 480-90

Scholes R. J. \& Archer S. R. (1997) Tree-grass interactions in savannas. Annu Rev Ecol Syst 28, 517-44

Stace H. C. T., Hubble G. D., Brewer R., Northcote K. H., Sleeman J. R., Mulcahy M. J. \& Hallsworth E. G. (1968) A Handbook of Australian Soils. Rellim Technical Publications for CSIRO and International Society of Soil Science, Glenside

Stone C. \& Bacon P. (1995) Influence of insect herbivory on the decline of black box Eucalyptus largiflorens. Aust J Bot 43, 555-64

Tylianakis J. M., Didham R. K., Bascompte J. \& Wardle D. A. (2008) Global change and species interactions in terrestrial ecosystems. Ecol Lett 11, 1351-63

van der Waal C., de Kroon H., de Boer W., Heitkonig I. M. A., Skidmore A. K., de Knegt H. J., van Langevelde F., van Wieren S. E., Grant R. C., Page B. R., Slotow R., Kohi E. M., Mwakiwa E. \& Prins H. H. T. (2009) Water and nutrients alter herbaceous competitive effects on tree seedlings in a semi-arid savanna. J Ecol 97, 430-9

Volder A., Briske D. D. \& Tjoelker M. G. (2013) Climate warming and precipitation redistribution modify tree-grass interactions and tree species establishment in a warm-temperate savanna. Glob Change Biol 19, 843-57

Walter H. (1971) Ecology of tropical and subtropical vegetation. Oliver \& Boyd, Edinburgh

Wang W., Vinocur B. \& Altman A. (2003) Plant responses to drought, salinity and extreme temperatures: towards genetic engineering for stress tolerance. Planta 218, 1-14

Ward D. (2005) Do we understand the causes of bush encroachment in African savannas? Afr J Range \& Forage Sci 22, 101-5

Ward D. \& Esler K. (2011) What are the effects of substrate and grass removal on recruitment of Acacia mellifera seedlings in a semi-arid environment? Plant Ecol 212, 245-50

Ward D., Wiegand K. \& Getzin S. (2013) Walter’s two-layer hypothesis revisited: back to the roots! Oecologia 172, 617-30

Western D. \& Maitumo D. (2004) Woodland loss and restoration in a savanna park: a 20-year experiment. Afr J Ecol 42, 111-21

Whalley R. D. B. \& Brown R. W. (1973) A method for the collection and transport of native grasses from the field to the glasshouse. J Range Manage 26, 376-7 
505 Wiegand K., Saltz D. \& Ward D. (2006) A patch-dynamics approach to savanna dynamics and woody 506 plant encroachment - Insights from an arid savanna. Perspect Plant Ecol Evol Syst 7, 229-42

507

Wiegand K., Ward D. \& Saltz D. (2005) Multi-scale patterns and bush encroachment in an arid savanna 508 with a shallow soil layer. J Veg Sci 16, 311-20

509 Wilson S. D. \& Keddy P. A. (1986) Measuring diffuse competition along an environmental gradient: 510 results from a shoreline plant community. Am Nat 127, 862-9

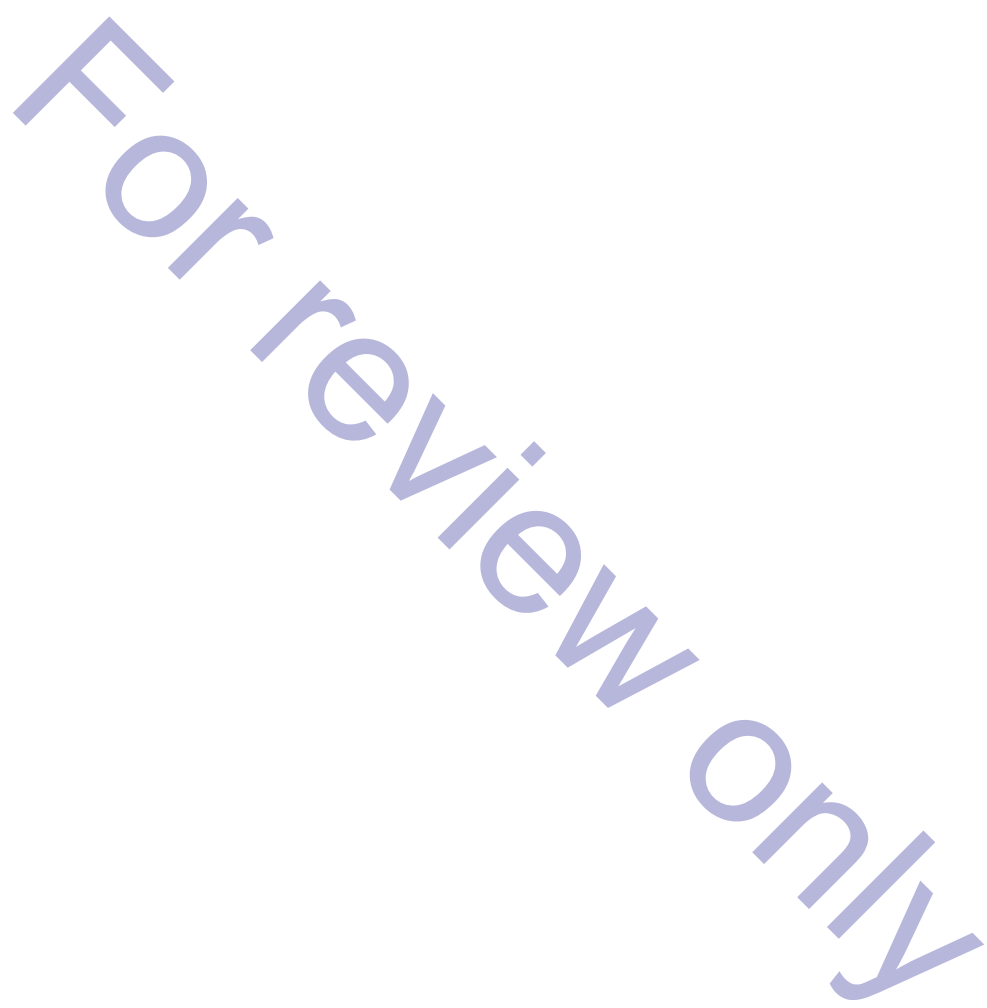




\section{Tables}

Table 1. Tree seedling responses to treatments after 227 days in the winter field. Values are mean \pm SE for Grass and Shade; *No error available for BARE plots because only one individual remained at the end of the study. Seedlings pooled across all sites; means within rows followed by a different superscript differ significantly (Bonferroni, $P<0.05$ ).

\begin{tabular}{lccc}
\hline Final tree seedling size & \multicolumn{3}{c}{ Treatment } \\
& Bare* $^{*}$ & Grass & Shade \\
\hline Height (mm) & 200.0 & $109.7 \pm 11.4^{\mathrm{a}}$ & $272.9 \pm 27.9^{\mathrm{b}}$ \\
Total mass (g) & 2.7 & $0.3 \pm 0.1^{\mathrm{a}}$ & $2.2 \pm 0.6^{\mathrm{b}}$ \\
Above-ground mass (g) & 1.1 & $0.2 \pm 0.1^{\mathrm{a}}$ & $1.7 \pm 1.7^{\mathrm{b}}$ \\
Number of surviving & 1 & 17 & 14 \\
seedlings & & & \\
\hline
\end{tabular}
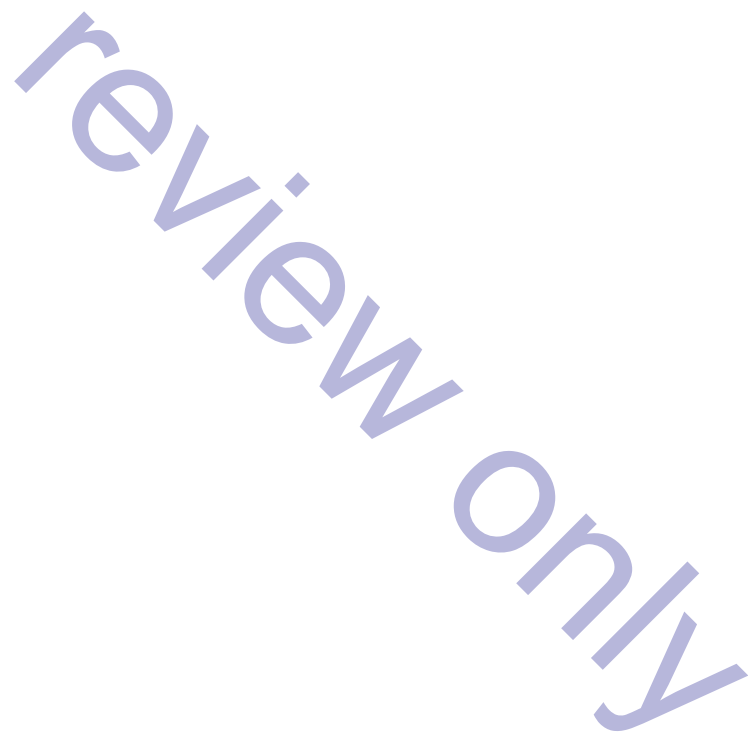
Table 2. Seedlings growth (change in seedling height in response to root competition $(+=$ with; - = without) for the first and second 3-month periods in the winter transplant experiment. Values are mean ( \pm SE) (sample size). Means followed by different superscripts were significantly different (Bonferroni, $\mathrm{P}<-0.05$ ). Sample sizes in parentheses (n).

\begin{tabular}{|c|c|c|c|c|c|c|}
\hline \multirow{2}{*}{ Time period } & \multicolumn{2}{|c|}{ + Roots } & \multicolumn{2}{|c|}{ - Roots } & \multicolumn{2}{|c|}{ Light levels pooled } \\
\hline & Low light & High light & Low light & High light & + Roots & - Roots \\
\hline First 3 months & $22 \pm 2(42)$ & $30 \pm 3(20)$ & $24 \pm 3(37)$ & $24 \pm 4(15)$ & $25 \pm 2(62)$ & $24 \pm 2(52)$ \\
\hline Second 3 months & - & - & - & - & $83 \pm 10(18)^{\mathrm{a}}$ & $172 \pm 23(19)^{\mathrm{b}}$ \\
\hline
\end{tabular}

Means followed by different superscripts were significantly different (Bonferroni, $P<0.05$ ). Sample sizes in parentheses $(n)$.

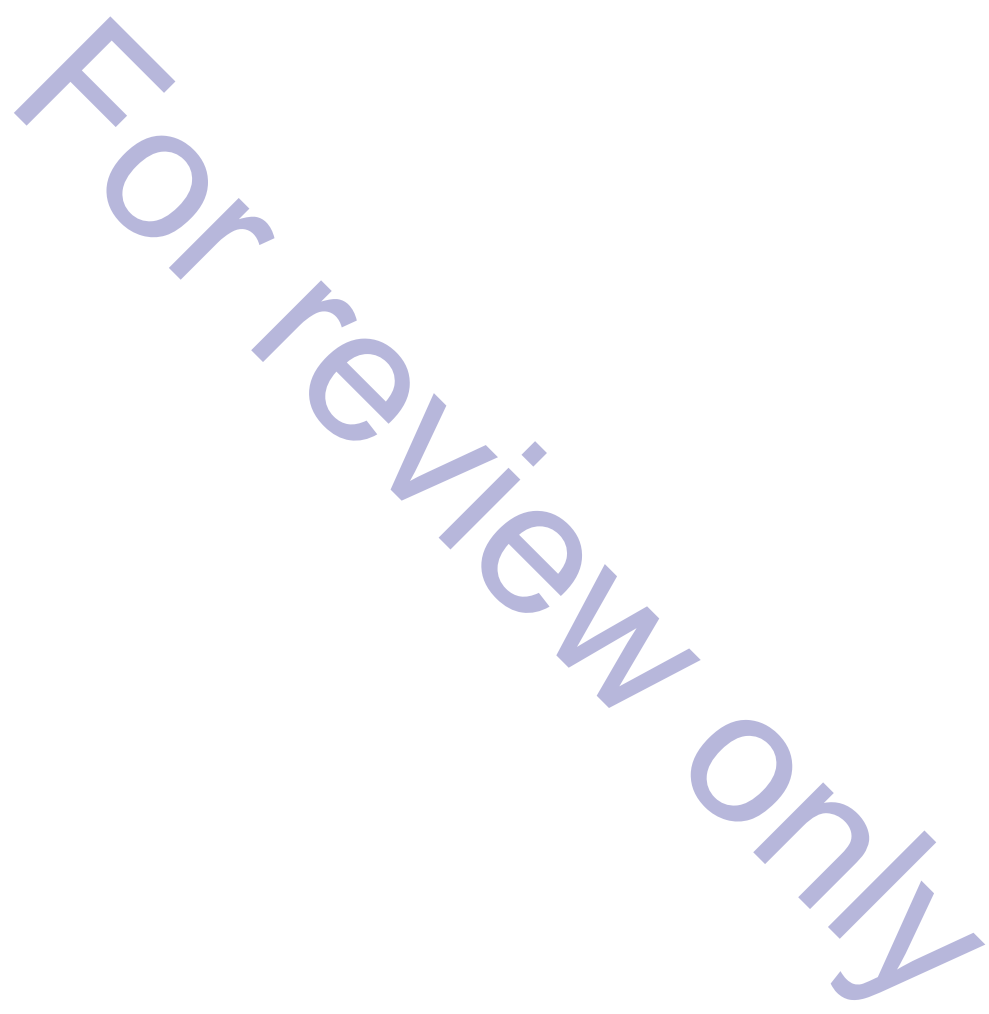




\section{Figure Legends}

Fig. 1 Maximum daily soil surface temperature (mean \pm SE) for the 2 weeks following seedling transplant in the three treatments (bare, grass and shade) in summer (black) and winter (grey)

Fig. 2 Coolibah tree seedling survival (mean \pm SE) in 'Bare', 'Grass' and 'Shade' treatments from the summer experiment in the 3 weeks after planting

Fig. 3 Coolibah tree seedling survival (mean \pm SE) in 'Bare', 'Grass' and 'Shade' treatments from the winter experiment in the 7 months after planting

Fig. 4 Coolibah tree seedling growth in 'Bare', 'Grass' and 'Shade' treatments from the winter experiment in the 7 months after planting. Values are seedling height (mean \pm SE)

Fig. 5 Relative competition intensity (mean $\pm \mathrm{SE}$ ), based on coolibah tree seedling growth with two grass tussocks ( $2 \times$ Grass) or four grass tussocks ( $4 \times$ Grass); grasses were clipped (Short) or unclipped (Long)

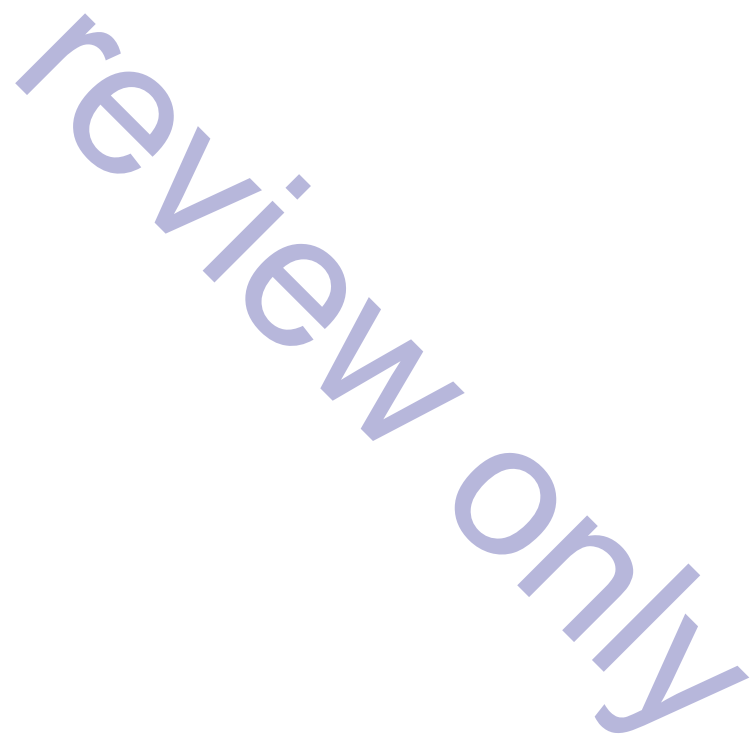




\section{Figures}

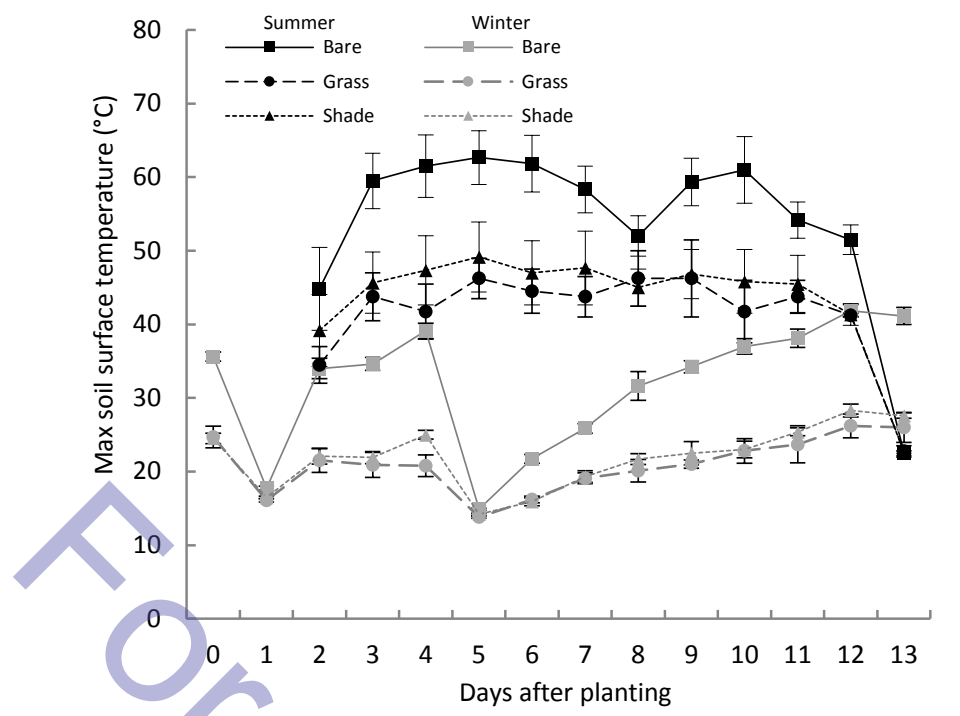

Fig. 1

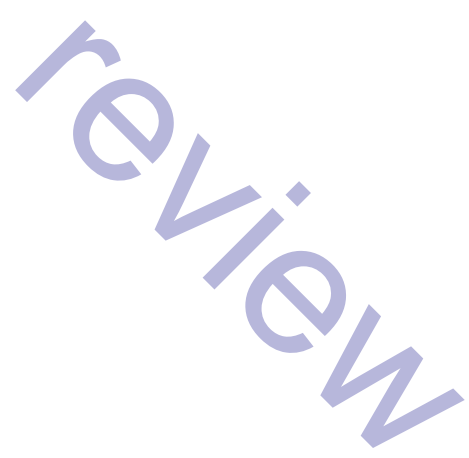




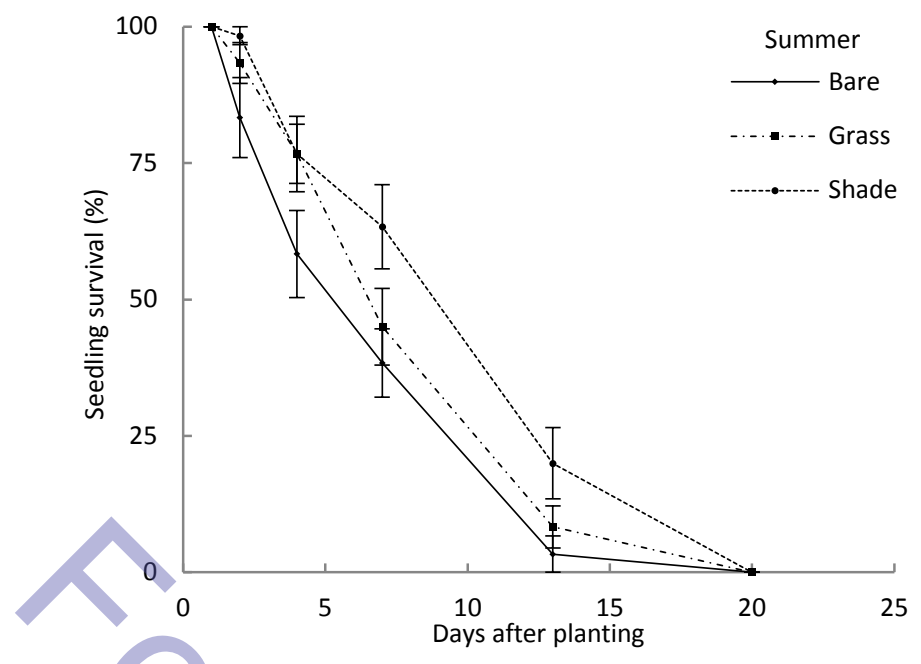

Fig. 2 


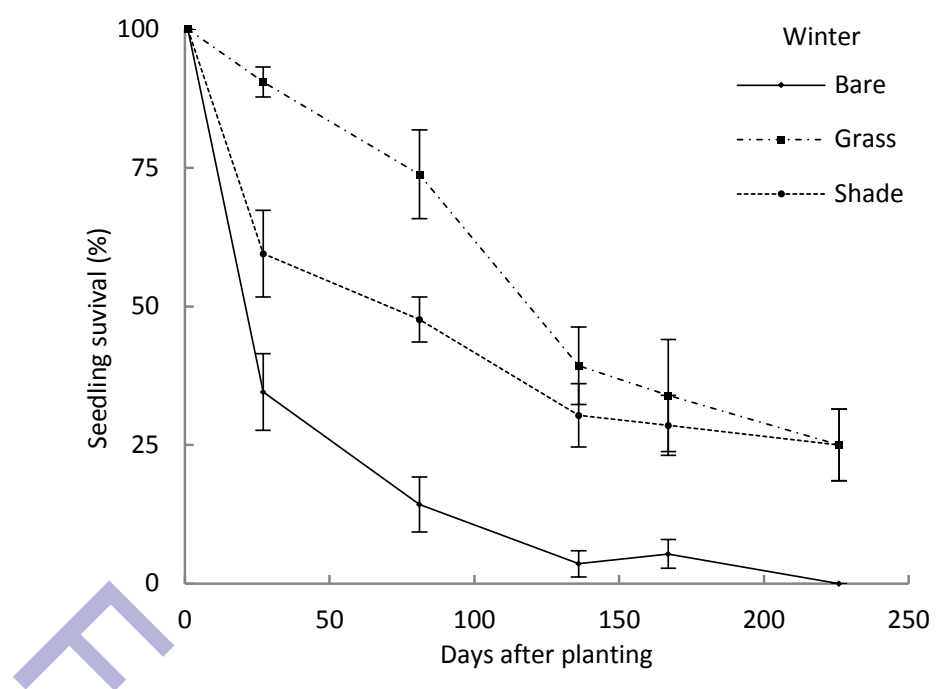

Fig. 3 


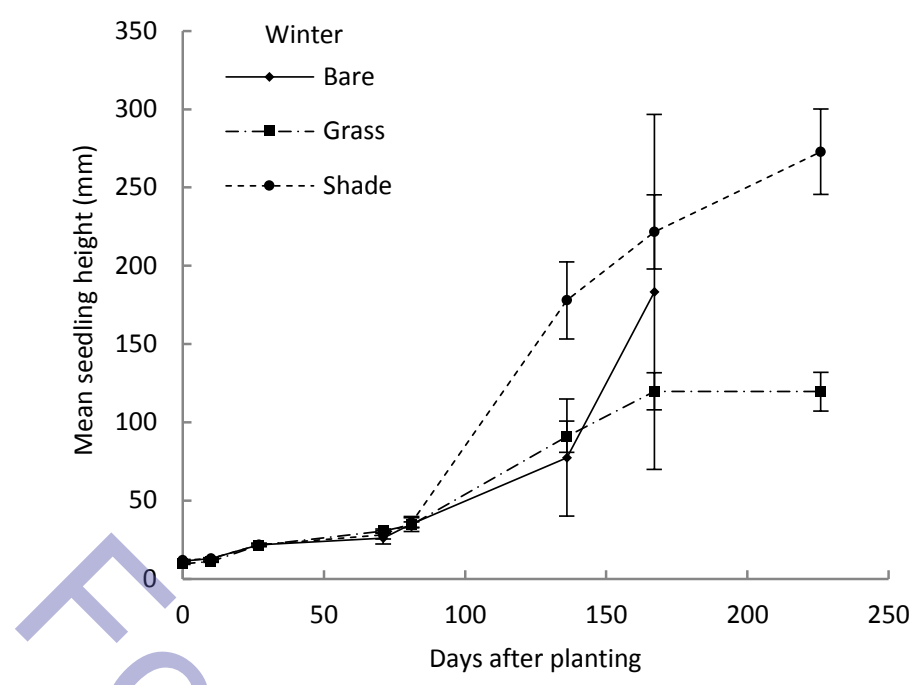

Fig. 4
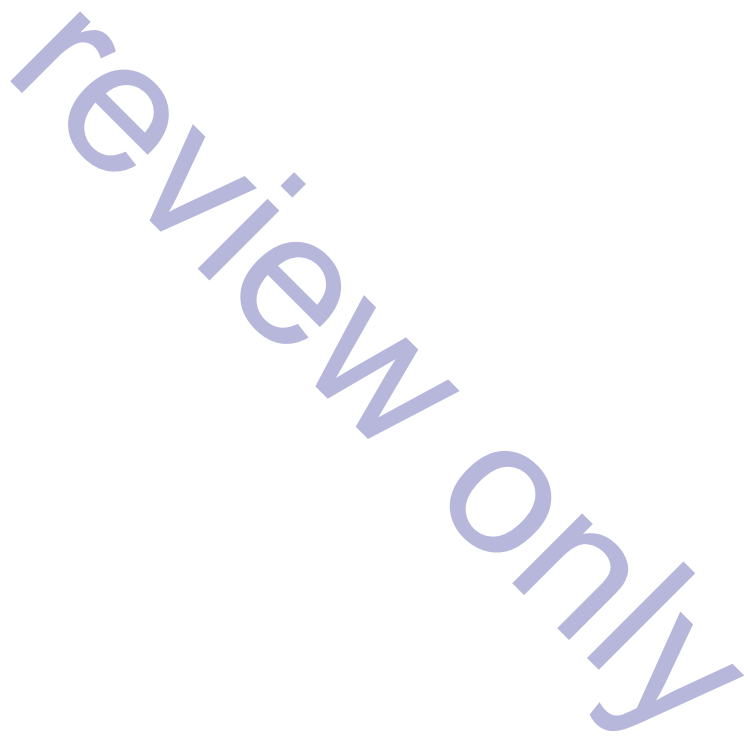


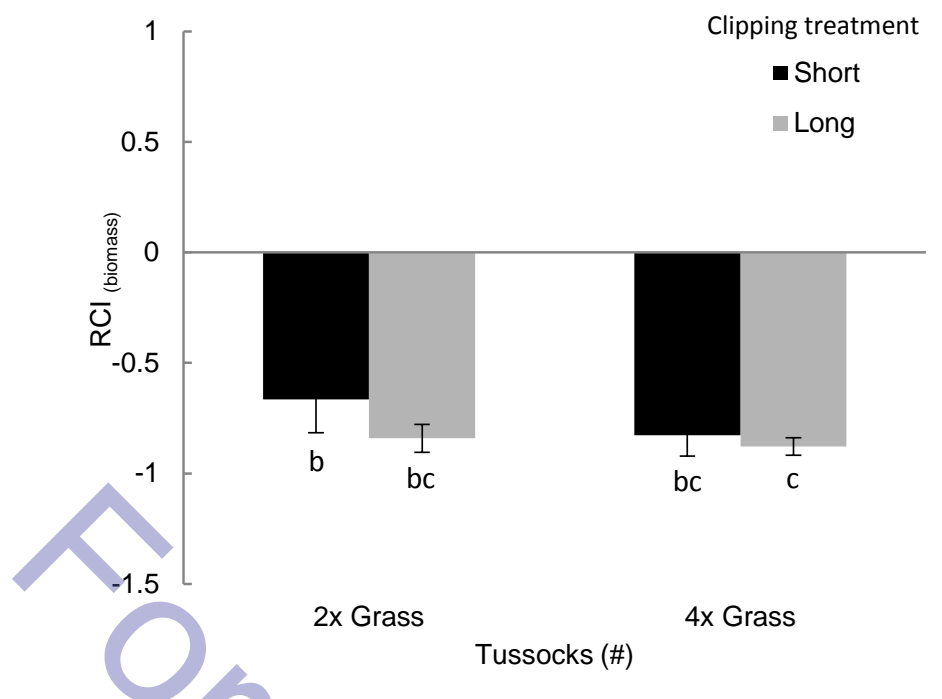

Fig. 5

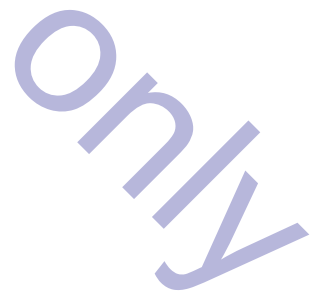

